\title{
Media for sex education in elementary school: Which one is better
}

\author{
Luluk Nandya Maharani *, Sigit Sanyata \\ Department of Guidance and Counseling, Program Pascasarjana, Universitas Negeri Yogyakarta. \\ Jalan Colombo No 1, Karangmalang, Yogyakarta, 55281, Indonesia \\ * Corresponding Author. E-mail: luluknandya16@ gmail.com
}

Received: $9^{\text {th }}$ August 2019; Revised: $4^{\text {th }}$ September 2019; Accepted: $9^{\text {th }}$ September 2019

\begin{abstract}
The development of sex education media today is an important thing that must be observed. The media is one of the important components in the prevention of sexual abuse in children. Using the right media is expected to be able to provide knowledge about sex education that is adapted to the stage of child development and to avoid the danger of predators of violence and sexual abuse. This study aims to review the literature in the delivery of sex education in elementary schools using electronic and print media. The results or a review of this discussion indicate that print media is better and more effective in delivering sex education in accordance with the child's growth period. The results are expected to provide information that can be used as a theoretical basis for further research in the use of sex education delivery media for elementary students
\end{abstract}

Keywords: electronic, sex education, media, print out

How to Cite: Maharani, L., \& Sanyata, S. (2019). Media for sex education in elementary school: Which one is better?. Psychology, Evaluation, and Technology in Educational Research, 1(2), 117-124. doi:http://dx.doi.org/10.33292/petier.v1i2.27

\section{INTRODUCTION}

The development of sex education media today is an important thing that must be observed with the aim to convey the material of sex education properly to children. The use of media to convey sex education is expected to reduce sexual violence experienced by children. Chambers (2013) stated, it needs programs or learning, materials and media applied to children when children are at school as the role of reducing sexual violence against children. This step aims to provide children's knowledge of the dangers of predators of violence or sexual abuse and the child can protect themselves from these dangers. The development of the role of sex is divided into five phases namely the oral phase, anal phase, phallic phase, latent phase, and genital phase Sigmund Freud (Santrock, 2012, pp. 25-26). Furthermore, Sigmund Freud stated (Santrock, 2012, pp. 25-26), the stages of psychosexual development for elementary school-age children (6 years to puberty) are on latent stages in which students suppress sexual desire, instead develop social and intellectual skills. Moreover, Freud stated that sexual desire in the latent phase is the child's sexual interest which develops and changes. This phase is divided into two, namely the beginning and the end. In the beginning, children no longer pay attention to sensations felt by their genitals, while at the end, children begin to recognize sexual urges and interests to the opposite sex (Andika, 2010, pp. 47-48). To prevent children from sexual desires in a bad way, necessary to apply an understanding of sex education. And, delivery of sex education in primary school children might better use media to support the learning. Sex education delivered using the media is expected more acceptable and understandable by children, and then, surely, it will provide understanding as a preventive way from predators of sexual violence (Chasanah, 2018).

In learning delivery, the teacher of guidance and counseling (BK) should have skills or tactics with the aim of the delivery of provided material that is not monotonous or boring. In line with this statement, Alhadi, Supriyanto, and Dina (2016) stated that teachers of guidance and counseling (BK) must do innovation in providing material and services of BK. The innovation is such as the use of media to deliver the material. Fisher, Telljohann, Price, Dake, and Glassman (2015) stated, the topic or 
material on sex education should deliver since the age of elementary school. In addition to the material learned at school, parents must also participate to begin discussing sex education at home when the children enter the age of elementary school. The material of sex education consists of differences between women and men, sexual orientation, and body parts. Goldman and Coleman (2013) stated that teacher in elementary school is often assigned to provide puberty/sexuality education for students who experience sexual maturity at an earlier age. The material delivery is usually more acceptable using tools or supporting media.

Discussing providing an understanding of sex education at age of elementary school is always linked to the appropriate media to support the material delivery following the development and learning phases that will make children more interested, focused and interactive. Research on media for the delivery of sex education in elementary school children is currently divided into two media which consider as the best for delivering sex education material. First, the media is print media. Lestari and Sudaryanto (2006) found out that the Wayang Kagok media is an effective media and easy to carry to anywhere and one of a print media. Sa'ida and Rahayu (2018) discuss the use of Wabosang (wayang pairs and puzzle) as a medium for sexual education in children who live along the red bridge river in Surabaya (2018). Not only print media, but electronic media are also often used to deliver sex education. Rilianti and Ima (2011) stated that modern electronic media, such as a gameplay study used to deliver the material of sex education for children aged 8-9 years on the parts of the body which should not touch by others. Padillah (2018) stated that the best media used in the delivery of sex is multimedia-Android based media.

The particular research aimed to review the literature on the theory of media used in material delivery on sex education for children in elemefntary school. The research also examined which media were more effectively used for children in elementary school. The study also found out the strengths and weaknesses of each media as a tool/media in learning about sex education. The purpose of this study was to review the literature on the advantages and disadvantages of print and electronic media in learning about sex education in elementary schools.

\section{METHOD}

The particular research was a literature study that examined the results of previous studies on the media used in the delivery of sex education in elementary school. The media of the study were print and electronic media which both are still being debated as to which media is better in the delivery of material. This research was expected to examine the strengths and weaknesses of each media used to deliver the material.

\section{Result}

\section{RESULT AND DISCUSSION}

The results of research on the advantages and weaknesses of the media indicated that print media was better used for children in sex education because it was following the period of the child's growth and development. Furthermore, print media, in terms of price, was more affordable than electronics. The print media, such as Wayang Kagok, had a great influence on the understanding of male and female about the differences among reproductive organs. The questionnaire showed that 90.9 percent of female respondents and 57.9 male respondents were able to understand the reproductive organs. The Wabosang print media used as sexual education in early childhood. The Wabosang media as sexual education was very effective as a learning medium. The use of sex media using print media such as a guidebook can improve students' understanding. The T-test value was 3.666. With a significant level of $5 \%$ and $\mathrm{db}=38$, $\mathrm{t}$-table was 2.021 . In other words, $\mathrm{t}$-count $=3.666$ is higher than $\mathrm{t}$ table $=2.021$ (3.666> 2.021). In sum, the hypothesis of "Implementation of information services using guidebooks of sex education can increase the understanding of deviant sexual behavior."

\section{Discussion}

Print Media

Print media considered better in the learning delivery about sex education for elementary school. In line with the statement, Lestari and Sudaryanto (2006) stated that the Wayang Kagok is an effective media and easy to carry to anywhere due to it is a print media. Wayang Kagok as a media can use to 
convey sex education for children aged 7-12 years. Wayang Kagok media used to deliver material on the differences intimate organs between males and females. Also, the material was about how to behave to protect the reproductive organs to avoid others, such as predators or violence. Wayang Kagok Media used figures such as Gareng, Petruk, Bagong, and Bleguk which are usually used in the art of puppet, and they are familiar with the community. Wayang Kagok media was also practical and effective to use due to foldable for storage. In its use, Wayang Kagok media is also impressed while introducing Indonesian culture to children to instill a sense of nationality in children. Wayang Kagok Media also considered cheaper in its make and creation. The disadvantage of the Wayang Kagok media is, that not all children or teachers and parents understand how to use the Wayang Kagok. Furthermore, Lestari and Sudaryanto (2006) suggested, for print media, media must be universal and understood by all levels of society. Another weakness of this media was, the students can not understand $100 \%$ of the story in every detail, especially when the story was not explored fully reaching the actual condition.

Paramastri, Prawitasari, Prabandari, and Ekowarni (2011) stated that booklet media which is a print media was a good media to use and apply to students in elementary school. The advantages of this media are lightweight and easy to store. The booklet media used as a tool for the prevention of sexual violence in children aged 9-12 years. The booklet media considered good and in line with the development phase of children aged 9-12 years because, at this age, children start to interest in reading without the assistance of parents. However, the booklet media has some weaknesses, such as disseminating information on sex education for elementary school, the booklet media needs other supporting media. Also, the booklet media might be easy to lose. In addition, the booklet media is also very easy to thorn due to only a piece of paper. Media booklet is also not general, which means not everyone understands the booklet. The researcher further suggested using the right and appropriate word selection for the title with the aim the article is readable and easy to understand by the community. Media booklet of sex education (Kuku Pesek) has some functions, such as introducing the sexual education for children aged 3-6 years, providing knowledge about the importance of sex education to parents as a learning tool to their children's, and one of the very appropriate media following the development of children at age $3-6$ years (Hidayat, Mahanani, \& Putra, 2016).

Furthermore, he stated that learning using kuku pesek media has advantages and directly accepted by children. The reason is that this media is used with assistance from teachers or parents. Moreover, the form of this media can be a quarter circle shape if folded like a book so that the media $K u k u$ Pesek are lighter, no need much space and easy to carry to anywhere by the students or guide. In other words, the disadvantage of this media is on the small form of the media with small writing on it which makes it difficult for children to read because children aged 3-6 years are still not fully able in reading. Fitriyah (2016) stated that applying information services about sex education using a guidebook is very effective. The services can improve students' understanding of deviant sexual behavior. With the media books on sex education, students might understand better and easier to understand. The material may also be well received by students which impact on significant differences in the scores of understanding of deviant sexual behavior between before and after taught using sex education guidebooks. The guidebook must also compose following the age and stage of childhood development. This sex education guidebook also considers suitable and appropriate for students in understanding material, and the contents of books according to the children's age. Surely, it also has another disadvantage, such as having many pages which made the particular media is difficult to save compared to the current era as consider not practical.

Winarto (2017) developed the comic-based Buku Saku Pintar Anti Kekerasan Seksual (Smart Pocket Book on Sexual Violence or BUSAPAKSA) as a media in sexual learning for children of elementary school. The advantage of this media is, even the media like a pocketbook but it is designed like a comic with pictures. So, it can improve students' understanding of anti-sexual violence. The material in the comic-based pocket media is also adjusted to the age and development stage of children. By using this media, the children of elementary school focus on the teacher when is explaining about sex. This comic also conveys how to avoid the perpetrators of sexual crimes against children through smart info media. The story is compiled based on activities carried out by elementary school students in their daily lives. Comic media also consider being appropriate for the age of the children who more interest in visualized information, such pictures. Hopefully, this media is also able to increase the children's attention and focus on learning about sex education. Ninawati (2018) stated that a book is an 
appropriate media used for the delivery of sex education for elementary school-age children. The book of sex education is developed based on the analysis of students' needs and characteristics. Although they have various advantages, BUSAPAKSA also has a weakness, such as the students being confused to read the storyline of the picture whether start from the right or left first because this comic book consists of many pictures and text balloons. Today, the media of books also consider out of date in terms of shape or size of a thicker packing because comics usually have thick pages.

Meanwhile, Puspita (2017) stated, good teaching materials should able to help students understand the material delivered by the teacher. This sex education book is valid on expert tests, including subject material experts, media experts, and psychology. Moreover, it also conducted smallscale trials that obtained results that students are interested in using sex education books and increase students' insights and knowledge about sex education. Sex education books must be distributed on a broader scale with the aim of reducing sexual abuse and violence on children. And, children know how to protect themselves from the dangers of perpetrators or criminals of sexual violence. This book can be used by teachers or parents to convey sex education optimally. Sex education in primary school age is very important because the child enters the phallic phase at an early age of 4-6 years. Also, at this stage, the child feels their genitals as part of the fun. Therefore, a child likes to explore their genitals in this phase. In short, media or tools used in learning must follow its development.

Sa'ida and Rahayu (2018) reported the use of Wabosang (puppet pairs and puzzle or wayang bongkar pasang) as a media for sexual education in children along the Surabaya red bridge river (2018). The research showed that print media has several advantages, such this puppet media can use directly by pointing on any parts which should not be touched. This media is also equipped with removable clothes with the aim to introduce the children how to dress modestly to avoid sexual violence. And it is practical, this media can also be accompanied by a story or fairy tale. Wabosang is effective in helping children in providing an understanding of sexual education. The effectiveness of wabosang is influenced by several factors, such as the interesting shape, easy to use and the delivery of the material. In sum, the sex education material provided through this media is easier to understand for children. The disadvantage of this media is on the puzzle form; so it is likely that some items will be lost if not properly maintained and stored after use. Damayanti, Anni, and Mugiarso (2018) stated that image media is very effective to enhance students' understanding of sex education. Students can focus their attention on the media image and concentration in listening to the material. This media is also in accordance with the child's growth period because, at this time, the child enters the concrete thinking phase. Also, this media can also make easier for children to understand the material. And, image media is also easier to store because it can be folded.

Ninawati (2018) stated that the development of the book as a media in the delivery of sex education materials was very effective. The development of books with attractive colors will able to make students to focus on material which affects understanding and comprehend the material of sex education. The development of this book media is also very helpful for teachers in providing learning, which teachers can teach students, such as using storytelling about sex education. Books can also be used many times so that they are effective at cost. The price of this book is also quite cheap compared to electronic media. Nurbaya and Qasim (2018) stated print media wrote about underwear rules aiming to prevent children from sexual violence. Print media are expected to provide material with images to convey about underwear. The material is how to use good underwear for elementary school children. Also, this book considers practical and easy to carry home by students. Then, the books may show to parents so that parents apply material about the importance of wearing underwear for elementary school children to avoid the danger of violent crime and sexual harassment. This print media is easily understood by the facilitators, both teachers, and parents. Print media also considers practical to carry everywhere. Arisandi (2018) stated that the material delivery of sex education on how to avoid sexual harassers may use the media of the guidance board. Guidance boards consider effective and easier to understand. The guidance board also consider helpful in answering the questions raised, expressing opinions/ideas possessed, listening to the instructions, and performing the instructions. Besides the advantages, the guidance board also has weaknesses such as each board can only be used for a few students in delivering material so it is not general. 
Psychology, Evaluation, and Technology in Educational Research, 1 (2), 2019, 121

Luluk Nandya Maharani, Sigit Sanyata

\section{Electronic Media}

Contrary to previous opinions which suggest that print media is the best media in the delivery of sex education in primary school. Research by Rilianti and Ima (2011) found out that a more modern electronic media is a gameplay study which used in material delivery for children aged 8-9 years regarding sex education about the body parts that might not be touch by no one else. In the play study game media, children see illustrations of the body parts that should not be touched. The advantage of this media is no need for any prints carried by children. She further stated that this media is appropriate with the development of modern times where almost most of the children aged 8-9 years can operate the internet. The media of play study game is accessible and studied at home with the parents' guidance due to electronic media. So, at any time, the media might open for media of sex education. However, this media has some weakness, namely that there are children who are not yet skilled in using computers and ease level of playing games need improvement. Septiani, Prawitasari, and Emilia (2016) stated that audio-visual media is better at delivering material of sex education. Audio-visual media will help kindergarten teachers to disseminate information about sexual education in preschool children. The material contains ways to avoid or fight the perpetrators of violence and sexual abuse and the things to do by children. With this audiovisual media, students are expected to focus longer on paying attention to the material in which the material will be well absorbed by children in kindergarten-age. But, the particular media has also several weaknesses, such as must have a stable internet network, need cable used to connect audiovisual with a laptop or Video Compact Disk (VCD) which is vulnerable being played by children or children may trip over the cable.

Hanafri, Mariana, and Suryana (2016) stated that the authors used the waterfall analysis method and Storyboard as a design method. This media contains sexual education material created using professional Adobe Flash CS6 software. The media contains material about learning and how to prevent and avoid the perpetrators of sexual abuse in early childhood. With the application of animation media of sex education, will deliver sex education material through sex education animation media that has been designed and adapted for children aged 3-5 years. These media consider the best because the media will attract children's interest. The delivery of material on sex education will also be more quickly conveyed and easily understood by children due to its visualized. This media is very helpful for teachers or instructors in delivering material because it makes the students more active and interactive, and having a feeling of pleasure in paying attention. The form of media on compact disc consider as a weakness. Also, inconvenient in using because they have to use supporting media to play.

Padillah (2018) argued that multimedia Android-based media is appropriate in the delivery of sex education. Android-based media is easier to apply because accessible using mobile phones. In its implementation, the conclusions are the Development of multimedia sex education applications using the V-Model method with stages of development, such as; need analysis, specification analysis, design, implementation, unit testing, integration testing, system testing, and acceptance testing. The value of the Functionality aspect is $100 \%$ in the "excellent" category. The Reliability aspect is $100 \%$ in the "Excellent" category. The Compatibility aspect is $100 \%$ in the "Excellent" category. And, the Playability aspect is $81 \%$ in the "good" category. Based on the trial results, the developed multimedia sex education applications obtained a percentage of $95.25 \%$. Based on the results, concluded that the quality standards of application meet the "very feasible" category. However, the weakness of this media is the user target of development in which children of early childhood still cannot operate by themselves. Hanum, Huda, and Kurniawan (2018) stated that video is a good media used to attract students' attention in sex education learning. This media is considered better and more effective because provide knowledge that will be easily understood by students. This media focuses on the material on how to deal with menstruation.

Ardiana and Loekito (2019) stated using a mobile or application is a good media used to deliver material about the dangers and ways to prevent violence and sexual abuse. This mobile-based media is very appropriate for children aged 6-12 years. Material on the prevention of violence and sexual harassment is important and must be known by children from an early age. This mobile contains information such as four body parts that should not be touched by anyone other than parents and doctors, in which the material will help children to avoid sexual harassment. This mobile-based multimedia is designed in a visual novel with two-dimensional cartoons, hopefully, attract the attention and interest of children. Mobile, here, is based on an android system so that it can be easily 
distributed and used. Selection with mobile android currently follow the development of an increasingly modern era, as well as the android system is one of the popular systems. Also, the selection mobile base is, by the current development of mobile technology, especially smartphones which experience rapid development and widely used. Android has been used by more than a million mobile devices in more than 190 countries around the world. Android is the largest installed base of all mobile platforms. Android was built with contributions from the Linux open-source community and more than three hundred partners of hardware, software, and operator. Android has quickly become the fastest-growing mobile operating system. Android provides tools to make applications look great and take advantage of the hardware capabilities on each device and provide a market place for selling and distributing applications (Holzer \& Ondrus, 2011).

The use of video for children aged 17 years is effective to increase understanding of the dangers of free sex among adolescents (Nurhidayati, 2013). In the end, video media deserves to be used as a media to support the guidance and counseling services, especially to increase understanding of the dangers of free sex among adolescents effectively and efficiently. The particular video media is created using windows movie maker, completed with manuals and accompanying material to guide students to understand the dangers of free sex among adolescents. So, counselors can use this media while providing counseling services. And, after using it, counselors should save and make sure everything is complete so that it can be reused in the future. The weakness of this media is that there is a need for other media to support the performance of this media to be maximized in its use. Palupi (2017) argued that animated video is a good media for the delivery of sex education among children with the aim to avoid and prevent sexual violence in children of kindergarten age. The main topics in this animated video are the body parts, the differences between the bodies of male and female, the person who can touch the body, and which body parts should not be touched by other people. Animated videos also have the advantage, such as being easily captured by children and more efficient in delivering the material. The developed animation video is appropriate for kindergarten age because contains elements of images that are easy to understand and colorful. But, this animated video also has a weakness, such a teacher must be good of operating it, but, in fact, some teachers are not capable of operating the media.

\section{CONCLUSION}

Based on the discussion of print and electronic media as a media in the delivery of sex education learning in elementary school have each advantage. Considering the advantage and weaknesses of these two media, then conclude that print media is better used in the delivery of sex education materials in primary school-age children. the suggestions for print media for further development are; the media should be used repeatedly, environmentally friendly and easily understood by teachers and parents as guidance in delivering material on sex education.

\section{REFERENCES}

Alhadi, S., Supriyanto, A., \& Dina, D. A. M. (2016). Media in guidance and counseling services: a tool and innovation for school counselor. SCHOULID: Indonesian Journal of School Counseling, 1(1). https://doi.org/10.23916/schoulid.v1i1.35.6-11

Andika, A. (2010). Bicara seks bersama anak. Yogyakarta: PT Suka Buku.

Ardiana, D. P. Y., \& Loekito, L. H. (2019). Perancangan multimedia interaktif untuk materi perlindungan anak terhadap pelecehan seksual berbasis mobile. SENADA (Seminar Nasional Desain Dan Arsitektur), 2, 216-222. Retrieved from https://eprosiding.stdbali.ac.id/index.php/senada/article/view/186

Arisandi, D. (2018). Papan bimbingan sebagai media pendidikan seks anak SD untuk mencegah pelecehan seksual. Universitas Muhammadiyah Surakarta.

Chambers, D. A. (2013). Preventing child sexual abuse: Effective elements for educational programs. Cambridge College.

Chasanah, I. (2018). Psikoedukasi pendidikan seks untuk meningkatkan sikap orangtua dalam

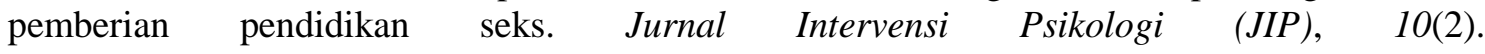
https://doi.org/10.20885/intervensipsikologi.vol10.iss2.art5 


\section{Psychology, Evaluation, and Technology in Educational Research, 1 (2), 2019, 123}

Luluk Nandya Maharani, Sigit Sanyata

Damayanti, M., Anni, C. T., \& Mugiarso, H. (2018). Layanan informasi dengan media gambar untuk meningkatkan pemahaman sex edukation siswa. Indonesian Journal of Guidance and Counseling: Theory and Application, 7(1). Retrieved from https://journal.unnes.ac.id/sju/index.php/jbk/article/view/17879

Fisher, C. M., Telljohann, S. K., Price, J. H., Dake, J. A., \& Glassman, T. (2015). Perceptions of elementary school children's parents regarding sexuality education. American Journal of Sexuality Education, 10(1), 1-20. https://doi.org/10.1080/15546128.2015.1009595

Fitriyah, F. (2016). Penerapan layanan informasi dengan menggunakan buku panduan pendidikan seks untuk meningkatkan pemahaman siswa terhadap perilaku seksual menyimpang di kelas VII B SMP Kartini Surabaya. Jurnal Bimbingan Dan Konseling Ar-Rahman, 2(2), 29-35. https://doi.org/10.31602/jbkr.v2i2.1055

Goldman, J. D. G., \& Coleman, S. J. (2013). Primary school puberty/sexuality education: studentteachers' past learning, present professional education, and intention to teach these subjects. Sex Education, 13(3), 276-290. https://doi.org/10.1080/14681811.2012.719827

Hanafri, M. I., Mariana, A. R., \& Suryana, C. (2016). Animasi sex education untuk pembelajaran dan pencegahan pelecehan seksual pada anak usia dini (Studi kasus di TK Kartini ). Sisfotek Global, 6(1). Retrieved from http://journal.stmikglobal.ac.id/index.php/sisfotek/article/view/96

Hanum, N. L., Huda, A., \& Kurniawan, A. (2018). Development of instructional video media in increasing sex education knowledge for students with hearing impairment. Jurnal Penelitian Dan Pengembangan Pendidikan Luar Biasa, 5(1). https://doi.org/10.17977/um029v5i12018p062

Hidayat, P. N., Mahanani, R., \& Putra, A. K. (2016). Kuku pesek (buku saku pendidikan seks) media edukatif pendidikan seksual anak. Pelita - Jurnal Penelitian Mahasiswa UNY, XI(2). Retrieved from https://journal.uny.ac.id/index.php/pelita/article/view/10932

Holzer, A., \& Ondrus, J. (2011). Mobile application market: A developer's perspective. Telematics and Informatics, 28(1), 22-31. https://doi.org/10.1016/j.tele.2010.05.006

Lestari, K., \& Sudaryanto, S. (2006). Pagelaran wayang Kagok sebagai media pendidikan seks pada anak di yogyakarta: Studi kasus terhadap siswa kelas III-VI SD Negeri Pakel, Yogyakarta. Pelita: Jurnal Penelitian Mahasiwa UNY, 1(2). Retrieved from https://journal.uny.ac.id/index.php/pelita/article/view/4333

Ninawati, M. (2018). Development of sex education books for elementary school students. JURNAL INDRIA (Jurnal Ilmiah Pendidikan Prasekolah Dan Sekolah Awal), 3(3), 212-220. https://doi.org/10.24269/jin.v3n3.2018.pp212-220

Nurbaya, S., \& Qasim, M. (2018). Penerapan pendidikan seks (underwear rules) terhadap pencegahan kekerasan seksual pada anak dan orang tua di SD Negeri 52 Welonge Kabupaten Soppeng. Media Kesehatan Politeknik Kesehatan Makassar, $13(2)$. https://doi.org/10.32382/medkes.v13i2.612

Nurhidayati, D. (2013). Pengembangan media video untuk meningkatkan pemahaman bahaya seks bebas di kalangan remaja SMA Negeri 1 Soko Tuban. Jurnal BK UNESA, 3(1). Retrieved from https://jurnalmahasiswa.unesa.ac.id/index.php/jurnal-bk-unesa/article/view/3444

Padillah, R. (2018). Pengembangan multimedia pembelajaran sex education berbasis android untuk anak usia dini. BaJET (Baturaja Journal of Education Technology), 2(2), 117-123. Retrieved from http://journal.unbara.ac.id/index.php/BaJET/article/view/10

Palupi, P. D. (2017). Pengembangan media video animasi pendidikan seks bagi anak usia dini guna mencegah kekerasan seksual pada anak di TK Tunas Rimba Purwokerto. E-Jurnal Skripsi Program Studi Teknologi Pendidikan, 6(7), 712-722. Retrieved from http://journal.student.uny.ac.id/ojs/ojs/index.php/fiptp/article/view/8412/0

Paramastri, I., Prawitasari, J., Prabandari, Y. S., \& Ekowarni, E. (2011). Buklet sebagai media pencegahan terhadap kekerasan seksual pada anak-anak. Jurnal Kesehatan Masyarakat Nasional, 6(2). https://doi.org/10.21109/kesmas.v6i2.109

Puspita, A. M. I. (2017). Pengaruh penggunaan bahan ajar tematik berbasis lingkungan terhadap 
Psychology, Evaluation, and Technology in Educational Research, 1 (2), 2019, 124

Luluk Nandya Maharani, Sigit Sanyata

aktivitas dan hasil belajar siswa kelas II SDN III Tanggung. Karya Ilmiah Dosen, 3(1). Retrieved from http://journal.stkippgritrenggalek.ac.id/index.php/kid/article/view/86

Rilianti, A. P., \& Ima, A. (2011). Play study: Educational game sebagai media belajar pendidikan seks bagi anak sekolah dasar. Pelita-Jurnal Penelitian Mahasiswa UNY, VI(2). Retrieved from https://journal.uny.ac.id/index.php/pelita/article/view/4275

Sa'ida, N., \& Rahayu, A. P. (2018). Penggunaan Wabosang sebagai media pendidikan seksual pada anak-anak bantaran sungai Jembatan Merah Surabaya. AKSIOLOGIYA: Jurnal Pengabdian Kepada Masyarakat, 2(1). https://doi.org/10.30651/aks.v2i1.1250

Santrock, J. W. (2012). Life-span development. McGraw-Hill Education.

Septiani, E., Prawitasari, S., \& Emilia, O. (2016). Efektivitas promosi kesehatan menggunakan audiovisual terhadap perubahan persepsi ibu tentang pendidikan seks untuk anak prasekolah. Berita Kedokteran Masyarakat, 32(11), 421-426. https://doi.org/10.22146/bkm.7528 